\title{
Global financial governance and the informal: limits to the regulation of money
}

\author{
William Vlcek ${ }^{1}$
}

Published online: 8 December 2017

(C) The Author(s) 2017. This article is an open access publication

\begin{abstract}
The list of predicate crimes for the Recommendations of the Financial Action Task Force (FATF) has evolved and grown over its twenty-five year existence. The evolution of this list reflects shifting concerns among the central actors in the organisation, as well as representing a response to any 'displacement' activity undertaken by those seeking to avoid these forms of governance. When the scope for cooperation and compliance with the FATF Forty Recommendations was extended beyond the organisation's membership this governance regime encountered business sectors and financial practices not readily amenable to its objectives. This paper considers the causes and consequences for the situation, as developing economy states attempt to comply with the global governance expectations of the FATF when a significant portion of the domestic economy operates 'informally'. A frame of reference is provided, with a definition for the informal economy and the concept of displacement as used in research on criminal activity. The focus here is with the nature of the cash economy operating beyond the scope of financial surveillance with implications for the comprehensive effectiveness of the global financial governance regime. The context of informal financial practice and its separation from the regulatory structures of the state leads to a conclusion that global financial governance is limited in practice to the domain of the formal economy.
\end{abstract}

\section{Introduction}

The scope of the Financial Action Task Force (FATF) has evolved and expanded from its starting point, which focused on money generated by illegal drugs trafficking deposited in banks, to include a variety of financial institutions and related businesses. This evolution of scope and coverage represents one response to 'displacement', the

William Vlcek

wbv2@st-andrews.ac.uk

1 School of International Relations, University of St Andrews, St Andrews, Fife, Scotland KY16 9AX, UK 
rational practice by which illicit actors seek an alternative means of monetary transfer/asset transformation when first banks and then other methods for monetary transfer were subjected to government surveillance and control. The widening scope of FATF governance brought the practitioners and officials representing the developed states that comprised its initial membership roster into contact with financial practices that, while operating at the margins of a developed economy, are widely used, if not essential, in a developing economy environment. It was that centrality of these informal economic practices in the developing economy which in turn produced unintended consequences and encouraged resistance to FATF guidance in those developing economies [1]. Moreover, in an analysis on local circumstances with respect to the FATF regulatory requirements, the costs of implementation and enforcement was felt to exceed any potential direct benefit accruing to the developing economy ([2]; see also, [3]). Such analysis further justifies resistance by developing states to the demands made by global governance institutions, when the threat from money laundering and/or terrorist finance in the local economy is deemed to be less than other sources of risk (including epidemics and the consequences from climate change for low-laying islands).

The challenge emerging from this set of circumstances involves the application of processes and procedures designed for the regulatory structures of a formal economy (frequently the dominant economic order found in a developed state) to an informal economy (conversely more likely to dominate economic transactions in a developing state). The dichotomy between the structure of an anti-money laundering (AML) regime and its practical implementation beyond the developing economy's limited formal financial sector reduces its effectiveness to control money laundering. Applying a process predicated on the implementation and enforcement of rules for data collection, identity verification, data retention and data reporting in an environment in which these processes achieve limited coverage is difficult. Though appearances can be deceiving, data may be collected and retained and identities known and remembered even in the informal economic environment when they are needed to conduct a successful and profitable business [4]. It may simply be the case for these businesses that the informality of their economic practices facilitates the avoidance of regulatory compliance (and the associated cost of compliance) in other aspects (health and safety regulations, labour laws, tax collection, etc.). Economic actors avoiding government regulation for other reasons have little motivation to comply with regulations for money laundering and terrorist finance, particularly if doing so would bring them to the attention of other government agencies. Moreover, in an economy where the percentage of the population that is 'unbanked' exceeds that percentage of the population with a formal bank account all of the surveillance processes that rely on the existence of a bank account and operate through the banking system have limited impact. The result then is a situation where a range of economic activity is effectively outside of the scope of mechanisms intended to stop money laundering.

The paper is developed across four sections with the next section outlining the evolution of the FATF's scope for its anti-money laundering regime. The following section extends that discussion beyond the FATF and its member states before moving to its attempt as a form of global financial governance to operate in the informal economic setting. The efforts made to implement an anti-money 
laundering regime when a substantial component of the national economy is cash-based rather than bank-based led to a further evolution of international AML guidance. The final section of the paper considers the nature of the FATF's evolving engagement with informal economies before offering some concluding thoughts.

\section{An evolving scope for the domain of AML}

The story for the origins of the Financial Action Task Force (FATF) is well-rehearsed ([5], p. 89-111; [6], p. 166-176; [7], p. 115-126; [8], p. 24-31; [9], p. 618-621). As discussed in more detail in the introduction for this special issue, the FATF was initially created to produce international standards to guide national efforts against the money laundering activity associated with illegal drugs trafficking [10]. The initial focus for the Forty Recommendations of the Financial Action Task Force on Money Laundering (1990) was drugs trafficking, emphasised in the first Recommendation for 'each country ... to fully implement the Vienna Convention' ([11], p. 2). ${ }^{1}$ The first eight Recommendations concern the implementation of the obligations laid out in the Vienna Convention, while Recommendations 12-29 are tasks to be performed by banks and non-bank financial institutions (per Recommendation 9). The experience with implementing the initial Forty Recommendations identified a number of areas requiring further explanation and subsequently addressed with the production of Interpretative Notes on individual Recommendations and a revision to the Forty Recommendations in 1996.

Subsequent to the introduction of Special Recommendations for terrorist finance in 2001 the core Forty Recommendations were revised once again. With the 2003 version of the Forty Recommendations the individual Recommendations included more text to better explain the purpose and function of the Recommendation (though more detailed Interpretive Notes remain part of the document). For example, the revised Recommendation 8 encouraged financial institutions to monitor new and emerging payment technologies for potential abuse by money launderers while the new Recommendation 12 specified a range of 'designated non-financial businesses and professions' which need to comply with the customer due diligence and record-keeping obligations placed on financial firms. This list comprised casinos, real estate agents, dealers in precious metals and stones, accountants, lawyers and other legal professionals, and trust and company service providers ([12], p. 4-5). And the United Nations Convention on Transnational Organized Crime (known as the Palermo Convention) is now identified alongside the Vienna Convention in Recommendation 1 as a precedent source for the criminalisation of money laundering ([12], p. 1).

In addition to the specifics identified in the Forty Recommendations document and the accompanying nine Special Recommendations on Terrorist Financing, the

\footnotetext{
${ }^{1}$ The Vienna Convention referred to here is the United Nations Convention Against Illicit Traffic in Narcotic Drugs and Psychotropic Substances, 1988, a necessary pre-condition for the criminalization of money laundering. Observe that the term 'money launder' is not present in this convention, rather it refers to the confiscation of the proceeds derived from the criminal activities listed in the convention (see Article 5).
} 
FATF has sponsored a series of reports to study both the actual practice of money laundering (at least as conducted by those who have been caught) and the potential for other areas of economic exchange to be utilised for laundering the proceeds of crime. These Methods \& Trends or Typology reports cover a variety of economic sectors, including some that may a first glace appear exceptional, such as the 2009 report on 'Money Laundering through the Football Sector' [13]. Other reports cover further potential avenues for money laundering, such as hawala and alternative remittance systems, corporate vehicles, trade and casinos [14-19]. Collectively, the experience from implementing the Recommendations and then evaluating the effectiveness of their implementation in combination with these studies led to a reorganised and rewritten Forty Recommendations that fully incorporated the standalone Special Recommendations on Terrorist Financing in 2012 [20]. The latest revision further expands the scope of the document with measures to include the proceeds of corruption and tax crimes as predicate offences to money laundering and measures to counter the financing of weapons of mass destruction. At the same time this latest version reflects a recognition for the difficulties encountered by some jurisdictions to effectively implement the AML regime crafted by the FATF. It now incorporates a 'risk-based approach', which facilitates reduced surveillance requirements for those identified as a low-risk for money laundering, such as the poor and unbanked. The risk-based approach is explained further below.

The purpose behind this brief summary of changes in the evolution of the FATF's mission to identify money laundering practices is to highlight the FATF's reaction(s) to the attendant evolution of practices deployed to avoid its prescribed surveillance mechanisms. The process of 'displacement' is a recognised concern in the criminology literature and frequently noted in studies on the effectiveness of policing techniques and practices. Displacement is defined as the movement of the criminal activity from one location, time, target, crime, method or criminal to a different location, time, target, crime, method or criminal ([21], p. 1333). It is an observed phenomenon in some criminology studies, for example with respect to the deployment of CCTV systems to reduce crime ([22], p. 510-513). While spatial displacement may be the most frequently seen form of the mechanism, displacement includes more than criminal activity simply moving to a different location ([21], p. 1333). At the same time, the actual measured presence of displacement is debated because if policing practices merely result in displacement then crime itself is not reduced by the direct efforts of law enforcement.

The term 'displacement' is not the only one used in the literature on the FATF and money laundering to identify this phenomenon. One alternative term is the 'balloon effect,' an analogy used to indicate that pressure placed on one point of a balloon pushes the air away to another point [23]. Similarly pressure placed on one form of money laundering forces the practice to other forms of money laundering ([24], p. 862). For the case of money laundering the argument made to expand and extend the coverage of anti-money laundering surveillance mechanisms to additional forms of economic exchange (e.g. real estate, on-line gaming or professional football) as well as beyond the core member states of the FATF was an increasing recognition of the displacement of money laundering practices to transactions and locations not covered by existing anti-money laundering surveillance ([25], p. 5-8; [8], p. 24; [26], p. 151). 


\section{The world beyond the FATF}

Beyond shifting to other means and techniques to conceal and transfer the proceeds of crime, the FATF was confronted in 1999 with increased evidence that money launderers were operating through institutions located in jurisdictions that were not members of the organisation. A 'typologies exercise' held by the FATF in November 1995 discussed recent trends in money laundering and a specific agenda item was the flow of illicit money from the 'former Soviet Union and Eastern Bloc'. One expert reported at the meeting that US\$40-50 million was believed to have entered that member state from the region ([25], p. 3). The larger extent of this spatial displacement from the former Soviet region was revealed, however, by an investigation of the Republic Bank of New York, which in turn identified the Bank of New York to US law enforcement authorities for failing to report suspicious transactions. It was far greater than suggested at the 1995 typologies meeting with an estimated US\$15 billion in suspicious Russian capital passing through the Bank of New York onward to Pacific island financial centres $[27,28]$. These revelations caused a small furore in the New York City banking community which responded by imposing private financial sanctions suspending all US dollar transactions with all banks located in Nauru, Niue, Palau and Tuvalu ([29], p. 244-251). The FATF would subsequently formalise these private sanctions as public sanctions through the production of its initial blacklist of 'non-cooperative countries and territories' in 2000 with the provision that all members of the FATF were obligated to enforce the financial sanctions $[30,31]$. It became a highly controversial action, particularly when the listed states pointed out the absence of other major financial centres, to include the New York City banks that were the initial financial institutions found to be complicit in suspicious Russian capital movements ([32], p. 93; [33]).

Indirectly the blacklist action served to impose the FATF's Forty Recommendations against money laundering on non-member states and jurisdictions. All cross-border financial transactions with the identified jurisdictions were to be considered 'potentially criminal' and subjected to close scrutiny. Once a jurisdiction was deemed by the FATF to be compliant with its rules and expectations, it would be de-listed, the final jurisdiction subjected to this blacklisting process was delisted in 2006 [34]. ${ }^{2}$ As a result of the more controversial aspects of the blacklisting process, the task of assessing and measuring compliance with anti-money laundering and terrorist financing obligations was assumed by the International Monetary Fund (IMF) under pressure from several large developed states to include it and as a reaction to the 2001 terrorist attacks. The assessments are conducted as part of the IMF's Financial Sector Assessment Program, significantly without the punitive features of the blacklist ([32], p. 94-98). However, since that transition the FATF felt obligated in 2007 to reassert its public identification of states failing in its assessment of their obligation to maintain adequate money laundering and terrorist financing controls [35]. The initial state of concern was Iran and the following spring the FATF expanded its list of deficient jurisdictions in order to 'protect the international financial system from abuse', and once again members states, and in fact 'all jurisdictions', are urged to 'advise their financial institutions to take the

\footnotetext{
${ }^{2}$ The specific experience of the Philippines with the FATF blacklist and the Philippine government's subsequent regulatory self-discipline is presented in [1].
} 
risk arising from deficiencies in [the named jurisdiction's] AML/CFT regime into account for enhanced due diligence' [36].

Additionally, in the aftermath of the 2001 terrorist attacks the FATF and other international organisations found the need to give greater attention to migrant remittance networks, otherwise known in the literature as informal value transfer systems. Remittances themselves and the role they perform in the economy of many developing states had been studied for a number of years, for example, the function of remittances for the economies of small Pacific island states [37, 38]. And one early typology report published by the FATF identified the use of 'remittance services' as a money laundering technique found in Asia, while the typology report released the following year provided more information on the operation of remittances services and hawala (the Arabic name for one method) as an 'underground banking' system that was 'almost always associated with ethnic groups from Africa and Asia' ([25], p. 10; [39], p. 7). These informal/ formal methods for transferring money across borders and long distances represented an unknown and in some aspects and locations an unregulated financial practice that could be misused for money laundering in addition to the financing of terrorism.

The initial concern identified in 2001 that significantly increased the attention given to remittance systems was a claim that the al Qaida terrorists used hawala to finance the attacks in the United States (see, e.g., [40]). That accusation was disproved in the Monograph on Terrorist Financing study prepared for the National Commission on Terrorist Attacks Upon the United States ([41], p. 139-140). The latter report does note that al Qaida in fact did make extensive use of hawala in connection with its move to Afghanistan in 1996 and thereafter while based in Afghanistan because the local banking system was inadequate ([41], p. 25). A World Bank study on the operation and use of hawala in Afghanistan opened with the assertion that the formal financial sector was 'virtually non-operational' in Afghanistan as a result of decades of conflict and explaining hawala's widespread use ([42], p. 1). The recognition that these informal remittance transfer systems represented a potential avenue for terrorist finance and money laundering outside of Asia or any identified ethnic community led to the production of specific measures that required they be formalised and regulated in order to reproduce the already existing surveillance mechanisms in place for the formal banking system and to prevent their mis-use for money laundering or terrorist finance. ${ }^{3}$ The informal nature and operation of remittance systems, as compared to the formal retail banking and financial architecture more familiar to most contributors of the FATF's Recommendations, guidelines and typologies underscored the need for improved engagement with informality and informal economies more generally.

\section{Informal economies and global financial governance}

Absent from this narrative are the informal economic practices that operate alongside the formal economy and extend beyond the practices employed for remittance transfers. By their very nature, and by definition, informal economies and informal financial transactions exist and operate beyond the scope of anti-money laundering practices. For the purposes of this discussion, the informal economy is understood as the economic

\footnotetext{
${ }^{3}$ The move to formalise the informal in the remittance transfer sector is explored in more depth in [43, 44].
} 
activity existing and operating outside the regulation and oversight of the government. As such, it is the state through its laws and regulations that determine what is informal by defining the activities that are determined to be legal and thereby demarcating the boundaries of the formal economy [45]. Everything declared explicitly illegal or implicitly not included inside the domain of state regulation exists in the 'informal' economy. This situation is particularly the case where there continues to be a demand for the banned goods and services which are then supplied through the informal economy.

Consequently the informal economy consists of a diverse collection of transactions, ranging from the sidewalk vendor to the street market, and including flea markets, food trucks, garage sales and unlicensed retail or manufacturing businesses, all of which operate to a greater or lesser extent throughout the world. Essentially any cash-in-hand or cash-only transaction for which tax is not collected nor paid is an informal economic activity. In other words the informal economy is a cash-based economy. ${ }^{4}$ The term 'informal economy' carries a connotation of illegality, and any untaxed economic activity by definition would be illegal. However, there is a distinction to be made between the fruit and vegetable seller that does not collect and report sales tax and the person selling heroin, even if operating in the same neighbourhood.

Informal economic practices are neither new nor unknown, while the practice will be as old as taxation the term 'informal economy' is credited to the staff of the Institute of Development Studies at the University of Nairobi, who introduced it to the authors of the International Labour Organization report 'Employment, incomes and equity: a strategy for increasing productive employment in Kenya' in 1972 [47]. Accepting that there is a flea market/jumble sale/garage sale every week somewhere, it also should be recognised that the informal market's economic contribution in the local community does not begin to compare with the contribution of Wal-Mart and its local competitors in town. Just how large or significant, then, is the informal economy? Naturally, this is a difficult question to answer because along with being untaxed and unregulated the economic activity of interest also is uncounted and not formally measured [48]. Attempts to measure clandestine economic activity, both of the licit variety as much as with the illicit variety, is inherently problematic and deeply political [49]. Nonetheless, measuring the size of the informal, or 'shadow', economy has been central to much of the research and publications of Friedrich Schneider, Professor of Economics at Johannes Kepler University, Linz, Austria. In a study assessing the size of the shadow economy over the period from 1999 to 2007 for a set of 162 states, the average for the period ranged from $66.1 \%$ (Bolivia) to $8.5 \%$ (Switzerland) [50]. Importantly for understanding the relative relationship between the prevalence of a sizeable informal economic sector with the global governance initiatives against money laundering, thirteen states were estimated to possess an economy with an informal sector comprising greater than $50 \%$ of official GDP, 136 states were estimated to have an informal sector forming between $15 \%$ and $50 \%$ of GDP, leaving thirteen states with an informal economy estimated at less than $15 \%$ of GDP ([50], Table 2). In the view of some observers the contrast between a formal economy and these informal or shadow

\footnotetext{
${ }^{4}$ The term 'cash-dominated' economy was used by Humphrey PB Moshi as a point of distinction with the informal economy. His point was that a cash-dominated economy operated equally well with both formal and informal financial practices [46].
} 
economies represents The Dark Side of Globalization containing forms of Deviant Globalization that are operating across Ungoverned Spaces [51-53].

Consequently the challenge for achieving effective enforcement of anti-money laundering legislation in these economies is hampered by the size and influence of the informal sector to serve as an alternative avenue for evading financial surveillance mechanisms. Moreover there are factors beyond just the cash-based informal sector which confront the developing economy when attempting to enforce its anti-money laundering legislation. In a consideration of the situation present in the Andean states of Bolivia, Columbia and Peru with money laundering and anti-money laundering enforcement activity Francisco E. Thoumi and Marcela Anzola identified three points of failure. These three factors combined to produce an 'inadequate environment' for the successful implementation of the anti-money laundering laws, providing an example for what is known in the comparative legal studies literature as a "legal transplant" ([54], p. 439). This concept means that while the national legislation followed the guidelines and templates offered by the FATF the result was the implementation of legislation that was ill-suited to the national political economy of these three states. In part this result was the product of a situation in which the formal and informal sectors of the national economy are heavily interconnected and intermixed such that the legislation failed to adequately address the entire sphere of economic transactions that are available for organised crime groups to launder their assets.

The first factor producing this inadequate environment is obviously the size of the informal sector in these three Andean states and the authors agree that the figures available are suspect, which they cite from an earlier study by Friedrich Schneider and Robert Klinglkmair [55]. The figures from Schneider, et al. [50] estimated the 'shadow economy' of Bolivia at $63.5 \%$ in 2007 , Colombia at $33.5 \%$ and Peru at $53.7 \%$. The second factor identified by the authors has a clear connection to the first, which is the small number of people with formal financial sector accounts in these states. Financial exclusion has been identified elsewhere as an unintended consequence of the antimoney laundering surveillance regime, specifically the formal identification requirements necessary to comply with the 'know your customer' obligation imposed on financial institutions [56]. For these Andean states, however, the know your customer requirement is not so much the barrier as is the condition of low 'bancarization' that preceded even the introduction of anti-money laundering legislation and which reflects a number of other barriers to financial inclusion that are present in these societies ([54], p. 442-444). Obviously a condition of low financial participation, where few citizens possess a formal bank account, creates a challenge when the central surveillance mechanism of the anti-money laundering regime is to monitor customer activity at/ with financial institutions. When a significant part of the state's financial activity occurs outside of financial institutions it is effectively invisible to the anti-money laundering surveillance regime. The final factor involves the issue of property rights, because the historical trajectory of Latin America, as former Spanish colonies, created a very skewed structure of land ownership leading to weak and ill-defined property rights today.

The problem produced by weak property rights for local efforts to enforce the antimoney laundering regime lays in the complication it creates for the use of asset seizure as a disincentive as well as a punishment for criminality. Thoumi and Anzola relate the difficulties experienced by governments to determine the ownership of assets seized 
from suspects and the subsequent need to maintain the operation of any seized businesses until a court determines that the assets may be sold by the government. In one example they relate that a boat seized by law enforcement for carrying cocaine, was subsequently rented out by the government administrator while waiting for the ownership question to be resolved and that the boat was seized a second time for once again transporting cocaine ([54], p. 452). This problem with seized criminal assets is not unique to Latin America; the Financial Times reported in 2012 of a move by business schools in Italy to provide a postgraduate course for 'would-be managers of ex-Mafia concerns.' The article outlined the experience of the manager for a hotel and conference centre seized in Sicily, noting that it was normal for the judicial system to spend years to determine ownership of the seized property and then approve its sale by the government, which could take several more years while a buyer for the property was sought [57]. . $^{5}$

The alternative outlets for economic transactions to launder money or facilitate terrorist finance when the formal financial system is barred by surveillance systems are 'new' in the sense of emerging to satisfy this demand to transform or transfer assets. Yet at the same time such practices have been present in society even before named the 'informal economy' in 1972. They may not be as convenient as a bank, nonetheless these informal methods offer the means to avoid the mechanisms of financial surveillance. As a form of migrant remittance transfer hawala is a long standing financial system that has operated in the absence of a modern banking system for centuries [59]. The practice of trade mis-invoicing also has a long history of use to get around government regulations, whether on tariffs, customs duties, capital controls or banned goods ([60], p. 33-48). Trade-based money laundering has received increased attention for the ability of trade to move economic value across borders with the appearance of legality. And the sums involved may be quite substantial, US law enforcement officials found US\$65 million during a raid in the Los Angeles Fashion District while investigating the use of clothing companies for trade-based money laundering between the US and Mexico [61]. The latter example represents yet another instance of the 'black market peso exchange' already familiar to the FATF as a form of trade-based money laundering ([62], p. 5).

Yet at the same there is an important connection to the informal economy which is not about money laundering (as such) but rather about the movement of goods that are smuggled or undervalued at point of delivery in order to avoid/evade import duties and customs tariffs. These trade practices serve to connect formal economy regulation with the informal economy named by some authors as 'low-end' globalisation or globalisation 'from below' [63-65]. The strategy is relatively simple for the cases described by these authors, in order to circumvent (evade) these duties and tariffs the trader includes a visit to a print shop listed on the business trip's itinerary to Hong Kong or Guangzhou. The print shop will produce a made-to-order purchase invoice reflecting the goods and the desired purchase price that will move the shipment through customs at the destination with the least amount of cost or problems. These practices to evade duties and tariffs on small-scale transnational trade blend in with practices of tradebased money laundering to skew trade data. When that trade data is analysed at the

\footnotetext{
${ }^{5}$ This aspect for dealing with criminal assets was further investigated by the UNODC Open-ended Intergovernmental Working Group on Asset Recovery in 2014 [58]
} 
aggregate level the discrepancy is identified as money laundering regardless for other purposes, potentially on a massive scale $[66,67]$. Yet it would be incorrect to identify the fraudulent behaviour involved in tariff evasion with the use of trade transactions to legitimise ill-gotten gains from other business activity, such as the transport and sale of illegal drugs [68].

\section{Engaging informality}

In recent years the FATF has responded to the problems raised by developing states as they struggled to implement the Forty Recommendations in their formal financial sectors. As noted above, the concern for increasing financial inclusion appears to be in confrontation with the surveillance mechanisms desired by the FATF. The resolution to this problem that emerged from the FATF was the introduction of risk assessment and the establishment of a 'risk-based approach' to address the problem with countering terrorist financing and money laundering. Over several publications this risk-based approach was developed, starting with high-level principles and procedures and then outlining how they could be implemented in a specific financial sector, including for example remittance transfer businesses [69-71]. This approach proposes the use of practices and procedures that are scaled to the perceived level of risk among the expected customer base, the type and size of transaction and the involvement of other (potentially suspicious) locations or destinations. Implementations of the risk-based approach have been analysed and criticised, however, for failing to be sufficiently adapted to the circumstances seen in operation with informal economic activity.

For the case of remittance systems, a study using Afghanistan and the United Arab Emirates as examples for the application of FATF regulatory requirements found that the risk-based approach had not been implemented as desired. The governments for these two states had implemented compliant enforcement measures for the formal financial sector and then applied those same measures to the informal financial sector. The result identified by the authors was an ineffective regulatory environment in which the surveillance practices used by a formal sector financial firm, for example the 'know your customer' requirement to record all identification details, were inappropriate to the 'working modalities' of the remittance transfer sector. These mechanisms were also resisted by remittance operators not simply because they were foreign and externally imposed, but also because they 'ignored important cultural, social and religious factors' ([72], p. 417). The increasing use of mobile phone technology for financial services, including remittance transfers, have brought that technology within the scope of antimoney laundering regulation and the application of a risk-based solution to surveillance requirements [1].

More broadly, the FATF Recommendations address cash at the point of entry to the financial system (cash bank deposits for example) and when it crosses the border in sums greater than 15,000 dollars or Euros [73]. Yet enforcement of the Forty Recommendations where large sums of cash are involved is not always comprehensive, for example, with real estate where reports on large cash property purchases are not made. The real estate sector has attracted attention for these large cash purchases, from the media in the UK and US leading to enhanced regulations in the US [74-76]. The 
concern with the role performed by cash is long standing. A guidance manual produced by the Commonwealth Secretariat a decade ago included recommendations on restricting the use of cash in a national economy ([77], p. 59). The advice has not changed substantially since that publication, restrict cash transactions above a certain amount, promote the use of the formal banking system, and eliminate high value denomination bills.

There are several difficulties revealed by the evolution of the FATF as an institution of global governance and its engagement with informal economies. First, the process of displacement leads the outside observer to compare the evolving and growing range of measures to prevent money laundering and terrorist finance as an adult variation to the children's game of Whack-A-Mole. Each newly identified typology of money laundering brought yet another form of economic exchange under the purview of the FATF (via revisions to the Forty Recommendations), leading money launderers to pursue further alternative means to legitimise illgotten gains. Second, the difficulties experienced when applying methods and techniques developed to monitor formal economic sector transactions to informal economic activities revealed the existence of prerequisites for successful implementation. It is not simply the fact that small informal remittance transfer businesses do not want to pay the cost for collecting and retaining customer data, it is also the fact that customers did not possess the formal identification documents necessary to facilitate compliance. Thus, the successful implementation of global governance mechanisms crafted by the FATF is dependent on other forms of local governance, to produce and certify identity documents, to maintain registries of citizens containing the identity data and to provide the means to verify identity on demand. In essence, while the formalisation of these informal sector economic actors is often proposed as the solution to the existence of an informal economy, the mechanisms to accomplish formalisation require institutional capacity which at present may be beyond the means and ability of the state in question. Moreover, the state may have other objectives behind the classification and documentation of its citizens and residents [78].

Which is not to say that technological solutions are not available, simply that they require resources and institutional capacity to implement and maintain. India is in the midst of a massive project to collect biometric data on all citizens. This 'unique identity' project will provide an online-accessible identity database which should reduce if not eliminate a range of current fraudulent and corrupt practices that deprive citizens without identity documentation of the government benefits they are due [79]. It is already being applied in India's banking sector as part of the industry's AML practices and explicitly to advance financial inclusion initiatives [80]. Similarly, Mexico has implemented an electronic invoicing system to collect business invoices as the mechanism to reduce tax fraud. This system has the additional consequence of shutting down the false invoice printing businesses that had facilitated an estimated loss of US\$3.4 billion in tax revenue between 2007 and 2009 in Mexico [81]. Nonetheless, the prerequisite for implementing global financial governance incorporating informal financial practices presumes a transition to formal practices. In order to achieve such a transition it is first necessary to construct its supporting infrastructure, of identity documents and the related forms of information necessary to know these customers. 


\section{Concluding thoughts}

On reflection, the evolution of the FATF's scope for anti-money laundering and its intersection with informal economic practices suggest the problem may be found in the structural approach undertaken by the organisation. The FATF prepares its Recommendations as general guidelines in order to fit diverse legal systems, yet also explicitly specifies the conduct of money laundering and the methods and techniques performed to achieve laundered money. The result is that having identified the head of a money laundering mole peeking out of the ground and whacking it, the targeted mole recovers and relocates to a different position using a different method requiring yet another whack on the head to suppress it. In structuring a regulatory regime, it is a choice between establishing principles for guidance, or crafting rules for implementation. Similar to regulating finance, this choice determines the capacity for responding to dynamic change and the emergence of new methods and techniques [82]. The application of anti-money laundering controls in an informal economy was a response to the displacement of money laundering activity from the formal economy. But a rules-based approach lacks the flexibility necessary for dealing with the nature of an informal economy. The implementation of the anti-money laundering surveillance mechanisms has been problematic and unevenly distributed. One response was to introduce a risk-based approach with an expectation for the rules-based methods to be scaled as appropriate for the locallyidentified level of risk. Actual practice may not match that expectation. At the same time, money laundering displacement in the formal sector is seen to have advanced yet further, with the identification of potential money laundering activity in the sale/ purchase of fine art and French vineyards ([83, 84], p. 27).

In a development further demonstrating the linkage between formal banking institutions and remittance transfer firms, many (if not most) formal retail banks have closed the accounts held by remittance firms $[85,86]$. The increased use of fines to punish banks for failing to maintain adequate anti-money laundering controls has prompted a rational actor response on the part of the banks, to identify and remove risky clients from their customer base [87]. In turn this rational response is likely to promote increased informality as the remittance firms are forced to find other avenues to transfer their customers' funds and that move is likely to place their operations outside the view of existing anti-money laundering surveillance [88]. The banks' process to reduce their risk is essentially 'forced displacement' though it has been named 'de-risking' and it creates a new problem for the FATF mission to secure the global financial system against illicit money [89]. The underlying tension is centred on the question - what is the objective? The answer for the FATF has been, and remains, to address criminality and terrorism by depriving it of financial resources and capabilities. The tension arises where the means for achieving the objective conflicts with other objectives for a government and society. If displacement is a rational response of the criminal or terrorist and it is reflected in their practices to find other methods of transferring cash or economic value, then the objective for the FATF has been achieved. The rigorous enforcement of anti-money laundering obligations on the formal sector appears to be forcing the informal, and potentially illegal, financial transactions, however, beyond the scope of financial surveillance altogether and as a result serving to circumvent the original objective for those obligations. 
Open Access This article is distributed under the terms of the Creative Commons Attribution 4.0 International License (http://creativecommons.org/licenses/by/4.0/), which permits unrestricted use, distribution, and reproduction in any medium, provided you give appropriate credit to the original author(s) and the source, provide a link to the Creative Commons license, and indicate if changes were made.

\section{References}

1. Vlcek, W. (2012). Power and the practice of security to govern global finance. Review of International Political Economy, 19(4), 639-662.

2. Sharman, J. C., \& Mistry, P. (2008). Considering the consequences: The development implications of initiatives on taxation, anti-money laundering and combating the financing of terrorism. London: Commonwealth Secretariat.

3. van Duyne, P., Harvey, J., \& Gelemerova, L. (2016). The Monty Python flying circus of money laundering and the question of proportionality. In G. A. Antonopoulos (Ed.), Illegal entrepreneurship, organized crime and social control: Essays in honor of professor Dick Hobbs (pp. 161-186). Cham: Springer International Publishing.

4. Ballard, R. (2005). Coalitions of reciprocity and the maintenance of financial integrity within informal value transmission systems: the operational dynamics of contemporary hawala networks. Journal of Banking Regulation, 6(4), 319-352.

5. Gilmore, W. C. (2004). Dirty money: The evolution of international measures to counter money laundering and the financing of terrorism (Third ed.). Strasbourg: Council of Europe Publishing.

6. Hülsse, R. (2007). Creating demand for global governance: the making of a global money-laundering problem. Global Society, 21(2), 155-178.

7. Jakobi, A. P. (2013). Common goods and evils? The formation of global crime governance. Oxford: Oxford University Press.

8. Sharman, J. C. (2011). The money laundry: Regulating criminal finance in the global economy. London: Cornell University Press.

9. Tsingou, E. (2010). Global financial governance and the developing anti-money laundering regime: what lessons for international political economy? International Politics, 47(6), 617-637.

10. FATF (1990a). Financial Action Task Force on money laundering report. Retrieved 21 March 2002, from http://www.fatf-gafi.org/.

11. FATF (1990b). The forty recommendations of the Financial Action Task Force on money laundering. Retrieved 21 March 2002, from http://wwwfatf-gafi.org.

12. FATF (2003b). The forty recommendations. Retrieved 30 June 2003, from http://www.fatf-gafi.org/.

13. FATF (2009a). Money laundering through the football sector. Retrieved 6 July 2009, from http://www. fatf-gafi.org/.

14. FATF (2003a). Combating the abuse of alternative remittance systems: international best practices. Retrieved 30 June 2003, from http://www.fatf-gafi.org./pdf/SR6-BPP_en.pdf.

15. FATF (2006b). The misuse of corporate vehicles, including trust and company service providers. Retrieved 28 November 2006, from http://www.fatf-gafi.org/pages/0,2966,en_32250379_32237277_1_1_1_1_1,00. html.

16. FATF (2006c). Trade based money laundering. Retrieved 18 July 2006, from http://www.fatf-gafi.org/.

17. Financial Action Task Force. (2009c). Vulnerabilities of casinos and gaming sector. Retrieved 2 May 2009. from http://www.fatf-gafi.org/

18. FATF (2010). Money laundering vulnerabilities of free trade zones. Retrieved 16 April 2010, from http://www.fatf-gafi.org/.

19. FATF (2013). The role of Hawala and other similar service providers in money laundering and terrorist financing. Retrieved 22 July 2014, from http://www.fatf-gafi.org/.

20. FATF (2012). International standards on combating money laundering and the financing of terrorism \& proliferation: The FATF recommendations. Retrieved 27 February 2012, from http:/www.fatf-gafi.org/.

21. Guerette, R. T., \& Bowers, K. J. (2009). Assessing the extent of crime displacement and diffusion of benefits: a review of situational crime prevention evaluations. Criminology, 47(4), 1331-1368.

22. Welsh, B. C., \& Farrington, D. P. (2004). Surveillance for crime prevention in public space: results and policy choices in Britain and America. Criminology \& Public Policy, 3(3), 497-526.

23. Mora, F. O. (1996). Victims of the balloon effect: drug trafficking and U.S. policy in Brazil and the southern cone of Latin America. The Journal of Social, Political and Economic Studies, 21(2), 115-140. 
24. Zagaris, B. (2001). Trends in international money laundering from a U.S. perspective. The International The Lawyer, 35(2), 839-865.

25. Financial Action Task Force. (1996). FATF-VII report on money laundering typologies. Retrieved 27 May 2006, from http://www.fatf-gafi.org/

26. Sheptycki, J. (2000). Policing the virtual launderette: Money laundering and global governance. In J. W. E. Sheptycki (Ed.), Issues in transnational policing (pp. 135-176). London: Routledge.

27. General Accounting Office. (2000). Suspicious banking activities: Possible money laundering by U.S. corporations formed for Russian entities. Washington, D.C.: General Accounting Office.

28. Minority Staff of the Permanent Subcommittee on Investigations. (2001). Report on correspondent banking: A gateway for money laundering. Washington, D.C: U.S. Senate Committee on Government Affairs.

29. van Fossen, A. (2003). Money laundering, global financial instability, and tax havens in the Pacific Islands. The Contemporary Pacific, 15(2), 237-275.

30. FATF (2000b). Report on non-cooperative countries or territories. Retrieved 6 February 2002, from http://www.fatf-gafi.org/.

31. FATF (2000c). Review to identify non-cooperative countries or territories: increasing the world-wide effectiveness of anti-money laundering measures. English. Retrieved 21 March 2002, from http://www. fatf-gafi.org/.

32. Gordon, R. K. (2010). The international monetary fund and the regulation of offshore centers. In A. P. Morriss (Ed.), Offshore financial centers and regulatory competition (pp. 74-101). Washington, DC: The AEI Press.

33. Sharman, J. C. (2009). The bark is the bite: international organisations and blacklisting. Review of International Political Economy, 16(4), 573-596.

34. FATF (2006a). Chairman's summary, Vancouver plenary, 9-13 October 2006. Retrieved 19 February 2007, from http://www.fatf-gafi.org/.

35. FATF (2007a). Chairman's summary, Paris plenary, 10-12 October 2007. Retrieved 17 October 2007, from http://www.fatf-gafi.org/.

36. FATF (2008a). Chairman's summary of the FATF plenary meeting in Paris, 27-29 February 2008. Retrieved 18 March 2008, from http://www.fatf-gafi.org/.

37. Bertram, G. (1993). Sustainability, aid, and material welfare in small south pacific island economies, 1900-1990. World Development, 21(2), 247-258.

38. Connell, J., \& Conway, D. (2000). Migration and remittances in island microstates: a comparative perspective on the South Pacific and the Caribbean. International Journal of Urban and Regional Research, 24(1), 52-78.

39. FATF (1997). 1996-1997 Report on money laundering typologies. Retrieved 3 March 2003, from http://www.fatf-gafi.org/pdf/TY1997_en.pdf.

40. Greenberg, M. R., Wechsler, W. F., \& Wolosky, L. S. (2002). Terrorist financing: Report of an independent task force sponsored by the council on foreign relations. New York City: Council on Foreign Relations.

41. Roth, J., Greenburg, D., \& Wille, S. (2004). Monograph on terrorist financing. Washington, D.C.: National Commission on Terrorist Attacks on the United States.

42. Maimbo, S. M. (2003). The money exchange dealers of Kabul: a study of the Hawala system in Afghanistan (world banking working paper no. 13). Washington, DC: The International Bank for Reconstruction and Development, The World Bank.

43. Vlcek, W. (2008). Development vs. terrorism: money transfers and EU financial regulations in the UK. British Journal of Politics and International Relations, 10(2), 286-302.

44. Vlcek, W. (2010). Alongside global political economy: a rhizome of informal finance. Journal of International Relations and Development, 13(4), 429-451.

45. Guha-Khasnobis, B., Kanbur, R., \& Ostrom, E. (2006). Beyond formality and informality. In B. GuhaKhasnobis, R. Kanbur, \& E. Ostrom (Eds.), Linking the formal and informal economy: Concepts and policies (pp. 1-18). Oxford: Oxford University Press.

46. Moshi, H. P. (2012). Implications of cash-dominated transactions for money laundering. Pretoria: Institute for Security Studies.

47. Bangasser, P. E. (2000). The ILO and the informal sector: an institutional history (no. Employment paper 2000/9). Geneva: International Labour Organization.

48. Tanzi, V. (1999). Uses and abuses of estimates of the underground economy. The Economic Journal, 109(456), F338-F347.

49. Andreas, P. (2010). The politics of measuring illicit flows and policy effectiveness. In P. Andreas \& K. M. Greenhill (Eds.), Sex, drugs, and body counts: The politics of numbers in global crime and conflict (pp. 23-45). Ithaca: Cornell University Press. 
50. Schneider, F., Buehn, A., \& Montenegro, C. E. (2010). New estimates for the shadow economies all over the world. International Economic Journal, 24(4), 443-461.

51. Clunan, A. L., \& Trinkunas, H. A. (Eds.). (2010). Ungoverned spaces: Alternatives to state authority in an era of softened sovereignty. Stanford: Stanford University Press.

52. Gilman, N., Goldhammer, J., \& Weber, S. (Eds.). (2011). Deviant globalization: Black market economy in the 21st century. New York: Continuum.

53. Heine, J., \& Thakur, R. (Eds.). (2011). The dark side of globalization. New York: United Nations University Press.

54. Thoumi, F. E., \& Anzola, M. (2010). Asset and money laundering in Bolivia, Columbia and Peru: a legal transplant in vulnerable environments? Crime, Law and Social Change, 53(5), 437-455.

55. Schneider, F., \& Klinglmair, R. (2004). Shadow economies around the world: what do we know? (working paper no. 1167). Retrieved 24 February 2005, from http://ssrn.com/abstract=518526.

56. Vlcek, W. (2015). Securitising money to counter terrorist finance: some unintended consequences for developing economies. International Studies Perspectives, 16(4), 406-422.

57. Sylvers, E. (2012). Managers of ex-mafia assets. Financial Times. Retrieved 12 November 2012, from http://www.ft.com/

58. United Nations Office on Drugs and Crime. (2014). Reported outcome of the expert group meeting on the management, use and disposal of frozen, seized and confiscated assets, held in Reggio Calabria, Italy, from 2 to 4 April 2014. Vienna: United Nations Office on Drugs and Crime.

59. Thompson, E. A. (2008). An introduction to the concept and origins of Hawala. Journal of the History of International Law, 10, 83-118.

60. Cassara, J. A. (2015). Trade-based money laundering: The next frontier in international money laundering enforcement. Hoboken: Wiley.

61. Audi, T. (2014). Federal agents raid Los Angeles garment businesses allegedly linked to drug cartels. Wall Street Journal. Retrieved 13 September 2014, from http://online.wsj.com/articles/federal-agentsraid-los-angeles-garment-businesses-allegedly-linked-to-drug-cartels-1410381381.

62. FATF (2000a). Report on money laundering typologies, 1999-2000. Retrieved 21 March 2002, from www.oecd.org/fatf/pdf/TY2000_en.pdf.

63. Mathews, G. (2011). Ghetto at the center of the world: Chungking mansions, Hong Kong. Chicago: University of Chicago Press.

64. Mathews, G., Ribeiro, G. L., \& Alba Vega, C. (Eds.). (2012). Globalization from below: The world's other economy. London: Routledge.

65. Mathews, G., \& Yang, Y. (2012). How Africans pursue low-end globalization in Hong Kong and mainland China. Journal of Current Chinese Affairs, 41(2), 95-120.

66. de Boyrie, M. E., Pak, S. J., \& Zdanowicz, J. S. (2005a). Estimating the magnitude of capital flight due to abnormal pricing in international trade: the Russia-USA case. Accounting Forum, 29(3), 249-270.

67. de Boyrie, M. E., Pak, S. J., \& Zdanowicz, J. S. (2005b). The impact of Switzerland's money laundering law on capital flows through abnormal pricing in international trade. Applied Financial Economics, 15(4), 217-230.

68. Soudijn, M. R. J. (2014). A critical approach to trade-based money laundering. Journal of Money Laundering Control, 17(2), 230-242.

69. FATF (2007b). Guidance on the risk-based approach to combating money laundering and terrorist finance: high level principles and procedures. Retrieved 17 July 2007, from www.fatf-gafi.org.

70. FATF (2008b). Guidance on capacity building for mutual evaluations and implementation of the FATF standards within low capacity countries. Retrieved 19 March 2008, from http://www.fatf-gafi.org/.

71. FATF (2009b). Risk-based approach: guidance for money service businesses. Retrieved 6 July 2009, from www.fatf-gafi.org.

72. Trautsolt, J., \& Johnsøn, J. (2012). International anti-money laundering regulation of alternative remittance systems: why the current approach does not work in developing countries. Journal of Money Laundering Control, 15(4), 407-420.

73. Financial Action Task Force, \& Middle East \& North Africa Financial Action Task Force (2015). Money laundering through the physical transportation of cash. Retrieved 1 March 2016, from www.fatf-gafi. org/publications/methodsandtrends/documents/ml-through-physical-transportation-of-cash.html.

74. Financial Crimes Enforcement Network (2016). FinCEN takes aim at real estate secrecy in Manhattan and Miami. Retrieved from https://www.fincen.gov/news_room/nr/pdf/20160113.pdf.

75. Pickford, J. (2015). Cash buyers account for four in ten London property transactions. Financial Times. Retrieved 12 October 2015, from http://www.ft.com. 
76. Story, L., \& Saul, S. (2015). Towers of secrecy: stream of foreign wealth flows to elite New York real estate. New York Times. Retrieved 9 February 2015, from http://www.nytimes.com/2015/02/08 /nyregion/stream-of-foreign-wealth-flows-to-time-warner-condos.html.

77. Commonwealth Secretariat. (2006). Combating money laundering and terrorist financing: A model of best practice for the financial sector, the professions and other designated businesses (2nd ed.). London: Commonwealth Secretariat.

78. Sadiq, K. (2005). When states prefer non-citizens over citizens: conflict over illegal immigration into Malaysia. International Studies Quarterly, 49(1), 101-122.

79. India's UID scheme: Reform by numbers (2012). The Economist, 51-52. Retreived 25 April 2012, from http://www.economist.com/node/21542763.

80. Amicelle, A., \& Jacobsen, E. K. (2016). The cross-colonization of finance and security through lists: banking policing in the UK and India. Environment and Planning D: Society and Space, 34(1), 89-106.

81. Tax collection in Latin America: Electronic arm-twisting. (2014). The Economist. Retreived 16 July 2014, from http://www.economist.com/node/21602274.

82. Eatwell, J. (2008). Principles versus rules. In P. Arestis \& J. Eatwell (Eds.), Issues in finance and industry: Essays in honour of Ajit Singh (pp. 8-28). Basingstoke: Palgrave Macmillan.

83. Cohen, P. (2013). Valuable as art, but priceless as a tool to launder money. New York Times, p. A1.

84. Tracfin. (2013). Rapport annuel d'analyse et d'activité 2012. Montreuil: Traitement du renseignement et action contre les circuits financiers clandestins.

85. Ensign, R. L. (2014). Fincen warns banks on axing customers. Wall Street Journal. Retrieved 29 November 2014, from http://blogs.wsj.com/riskandcompliance/2014/11/10/fincen-warnsbanks-oncutting-off-msb-customers/.

86. Moore, E. (2013). Barclays defends split with money transfer companies. Financial Times. Retrieved 22 September 2014, from http://www.ft.com.

87. Ensign, R. L. (2016). US banks cut off Mexican clients as regulatory pressure increases. Wall Street Journal. Retrieved 30 January 2016, from http://www.wsj.com/articles/u-s-banks-cut-offmexican-clientsas-regulatory-pressure-increases-1453545003.

88. Barry, R., \& Ensign, R. L. (2016). Losing count: U.S. terror rules drive money underground. Wall Street Journal. Retrieved 31 March 2016, from http://www.wsj.com/articles/losing-count-u-s-terrorrules-drivemoney-underground-1459349211.

89. FATF (2014). FATF clarifies risk-based approach: case-by-case, not wholesale de-risking. Retrieved 15 Nov 2014, from http://www.fatf-gafi.org/. 